Estimation of friction contribution in the behaviour of steel-concrete composite beams with flexible shear connectors
Gilson Queiroz

Dr. Mechanical Engineering,

Universidade Federal de Minas Gerais,

Dept. of Structural Engineering

Belo Horizonte - Minas Gerais - Brazil

gilson@dees.ufmg.br

\section{Hermes Carvalho}

Msc. Mechanical Engineering, Universidade Federal de Minas Gerais, Dept. of Structural Engineering

Belo Horizonte - Minas Gerais - Brazil

hermesc2000@yahoo.com.br

\section{Francisco Rodrigues}

Dr. Civil Engineering, Universidade Federal de

Minas Gerais, Dept. of Structural Engineering

Belo Horizonte - Minas Gerais - Brazil

francisco@dees.ufmg.br

\section{Michèle Pfeil}

Dr. Civil Engineering, Instituto COPPE, Civil

Engineering Program

Rio de Janeiro - RJ - Brazil

mpfeil@coc.ufrj.br

\section{Avaliação da contribuição do atrito no comportamento de vigas mistas aço-concreto com conectores de cisalhamento flexíveis}

\begin{abstract}
A shear connector, developed to be applied to a composite beam whose steel profile is a thin-walled box profile, displayed much greater flexibility than the conventional welded shear connector, leading to particular issues in the composite beam behaviour. One of these issues is the role played by friction at the interface between the steel profile and the slab which, under particular circumstances, may be relevant for serviceability limit states and also for ultimate limit states. The Brazilian and American Standards do not yet recognize the friction contribution in the behaviour of composite beams, though they recognize this contribution in composite slabs. This paper presents the experimental tests carried out with and without friction contribution on simple supported composite beams with flexible connectors and the numerical models developed to simulate the behaviour of the tested beams. The experimental tests revealed significant increases in strength and stiffness of the composite beam due to friction contribution and the comparisons between numerical and experimental results displayed good correlations.
\end{abstract}

Keywords: Composite Beam, Friction contribution to horizontal shear connection, flexible connectors.

\section{Resumo}

Um conector de cisalhamento desenvolvido na UFMG, para uma viga mista de aço-concreto, composta por um perfil metálico de parede fina, apresentou comportamento muito mais flexivel do que um conector convencional soldado. Devido a essa flexibilidade, o papel desempenhado pelo atrito na interface do perfil metálico com a laje de concreto pode se tornar relevante sob certas condições, tanto para os estados- limites de serviço como para os estados-limites últimos. As disposições normativas brasileiras e norte-americanas ainda não reconhecem a contribuição do atrito no comportamento de vigas mistas, apesar de reconhecerem essa contribuição em lajes mistas. Este trabalho apresenta os testes experimentais realizados com e sem a presença de atrito em vigas mistas simplesmente apoiadas com conectores flexiveis e os modelos numéricos desenvolvidos para simular o comportamento dessas vigas. Os resultados experimentais mostraram acréscimos significativos da resistência e da rigidez das vigas devidos à presença do atrito na interface concreto-aço. As comparações entre resultados experimentais e teórico-numéricos em termos de deslocamentos verticais para cargas crescentes mostraram boas correlações.

Palauras-chave: vigas mistas, atrito na interface entre laje e perfil, conectores flexiveis. 


\section{Flexible shear connector for cold formed profile and friction contribution}

The use of cold-formed profile (CFP) in Brazil's construction industry has increased not only for applications on secondary members such as purlins and space covering members for roofs and walls but also on primary components, such as building floor beams. Figure 1 shows a composite beam cross section in which the steel section is composed of a box CFP and the slab is also a composite member formed by the profile sheeting and concrete (steel deck with ribs perpendicular to the steel box profile).

The used shear connector combines a rivet with an internal thread driven in the plate hole and a high-strength bolt, as illustrated in Figure 2. This connector was innovatively adopted as a composite beam shear connector in order to avoid the application of traditional welded connectors to the thin-walled CFP while allowing a simple and practical installation procedure. Due to plate bearing plastic
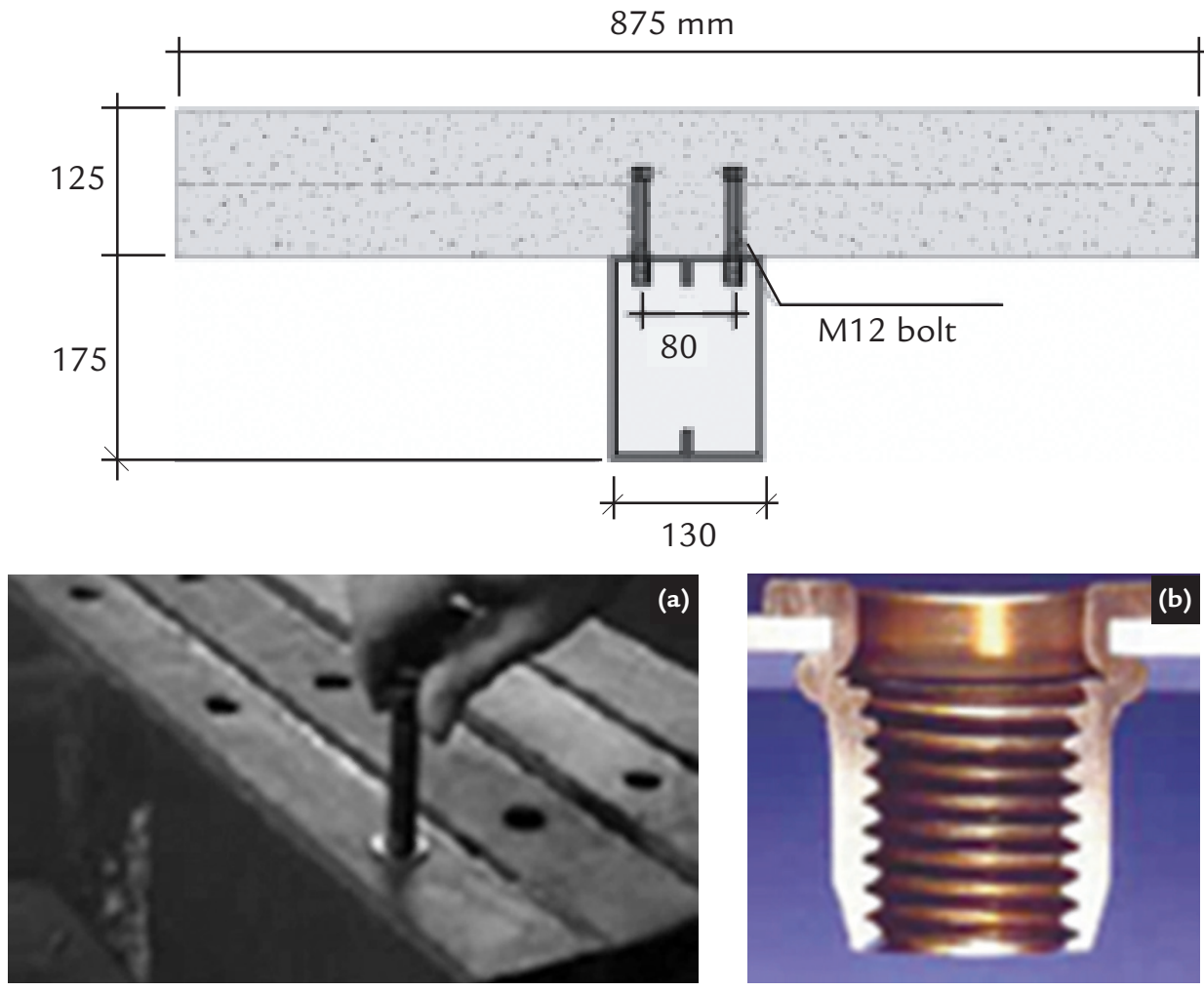

\section{Experimental analysis}

\subsection{Models description}

Aiming to estimate the friction contribution in the composite beam behavior the models for the experimental analysis were conceived on the basis of the conclusions drawn from previous studies (see section 1) with the following characteristics: short span equal to $3.5 \mathrm{~m}$ deformation (and hole ovalization) this shear connection revealed a much greater flexibility than a conventional connection with welded shear connector (BREMER, 2007), leading to particular issues in the composite beam behavior. One of these issues is the role played by friction at the interface between the steel profile and the slab which motivated a series of analytical, numerical and experimental studies developed at the Federal University of Minas Gerais, Brazil.

The strength and the stiffness of the connection between concrete slab and steel profile in composite beams depend basically on the number of shear connectors encased in concrete and their properties. In the case of flexible shear connectors the contribution of friction between the slab and the steel profile may be relevant for serviceability limit states and also for ultimate limit states, provided that the beam span is relatively short and the and flexible shear connectors.

The beam model cross-section is profile is formed from a $2 \mathrm{~mm}$ thick SAC300 steel plate $\left(f_{y}=300 \mathrm{MPa}\right)$. The slab is composed of $20 \mathrm{MPa}$ compressive strength concrete casted on a steel illustrated in Fig.1. The box section

slab stiffness is relatively large compared to that of the steel profile alone. These conclusions were drawn from previous analytical and numerical models allowing for the shear connectors' flexibility and friction between the slab and the steel profile (SILVA, 2009, QUEIROZ et al., 2009, OLIVEIRA, 2009, QUEIROZ et al., 2010). These results have not yet been included into the provisions of Brazilian (ABNT, 2008) and American Standards (AISC, 2005) which do not recognize the friction contribution in the behavior of composite beams, only of composite slabs.

This paper presents the experimental tests carried out to verify the role played by friction at the interface slab - steel profile in the behaviour of simple supported composite beam with flexible shear connectors. Also presented are numerical models developed to simulate the tested beams behavior whose results are compared to the corresponding experimental ones.

Figure 1

Composite beam cross section showing the box cold-formed profile (CFP), the steel deck slab with ribs perpendicular to the steel section and the shear connectors.

Figure 2

Shear connector.

(a) high-strength bolt,

(b) rivet with internal thread.

deck with ribs perpendicular to the steel profile.

Two series of models were tested, each one with two models, totalizing four tests. The models named F1 and F2 refer to beams with friction at the interface between slab and steel profile 
and the models NF1 and NF2 had no friction contribution. Figure 3 shows

Figure 3

Details of the slab-steel profile interface.

(a) models F1 and F2 with friction. (b) models NF1 and NF2 without friction.

The shear connectors (Figs. 2) were made of $12 \mathrm{~mm}$ diameter high-strength bolts (DIN 960 class 5.8 steel) and SAE 1040 rivets. Push-out tests performed in a similar composite beam with these shear

Figure 4 Load slip curves of the shear connection associated to one connector (BREMER, 2007). The curve fitted to the experimental points was adjusted to be used in the numerical model (see Section 3).

The beam was designed for full connection (governed by steel strength) resulting in 22 connectors almost uniformly distributed along each side of the midspan section.

Figure 5

Setup for experimental tests and model instrumentation (units:mm). the difference between the two series: the placement of teflon plates at the

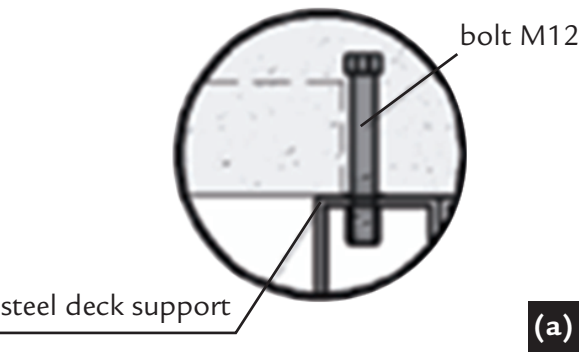

connectors and steel deck ribs parallel to the steel profile yielded the average load slip curve illustrated in Figure 4, from which one can calculate the initial stiffness associated to one connector equal to $70 \mathrm{kN} / \mathrm{cm}$. slab-steel profile interface in order to remove the friction force.

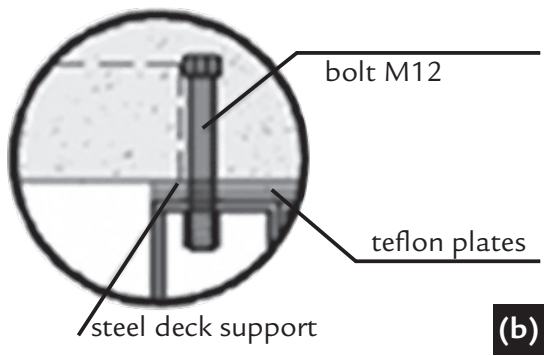

It is indeed a very flexible connector leading to partial interaction behavior of the composite beam. The low stiffness is due to bearing deformation of the $2 \mathrm{~mm}$ thick plate (and consequent hole ovalization).

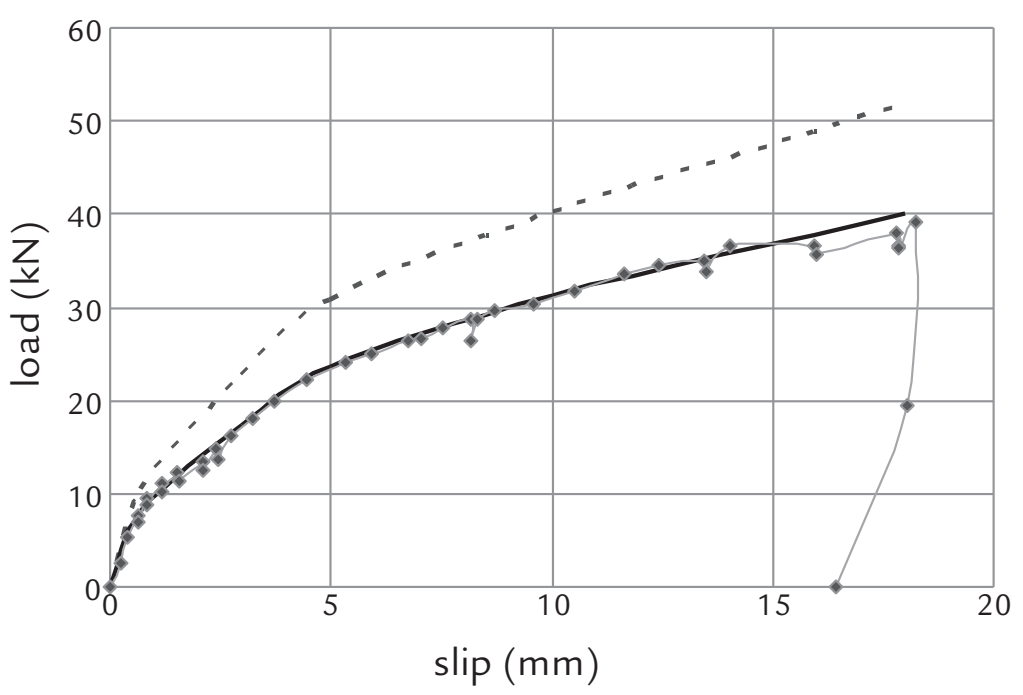

\footnotetext{
- - - adjusted curve - numerical model

- fitted curve

- experimental
}

The beam models were subjected to four concentrated forces in order to simulate a uniform loading. Figure 5 shows the test setup and the model instrumentation, which consists of dis- placement transducers (DT) at midspan and also at the beam ends to measure end slips, as well as several strain gages (EER) along the beam height at midspan section.

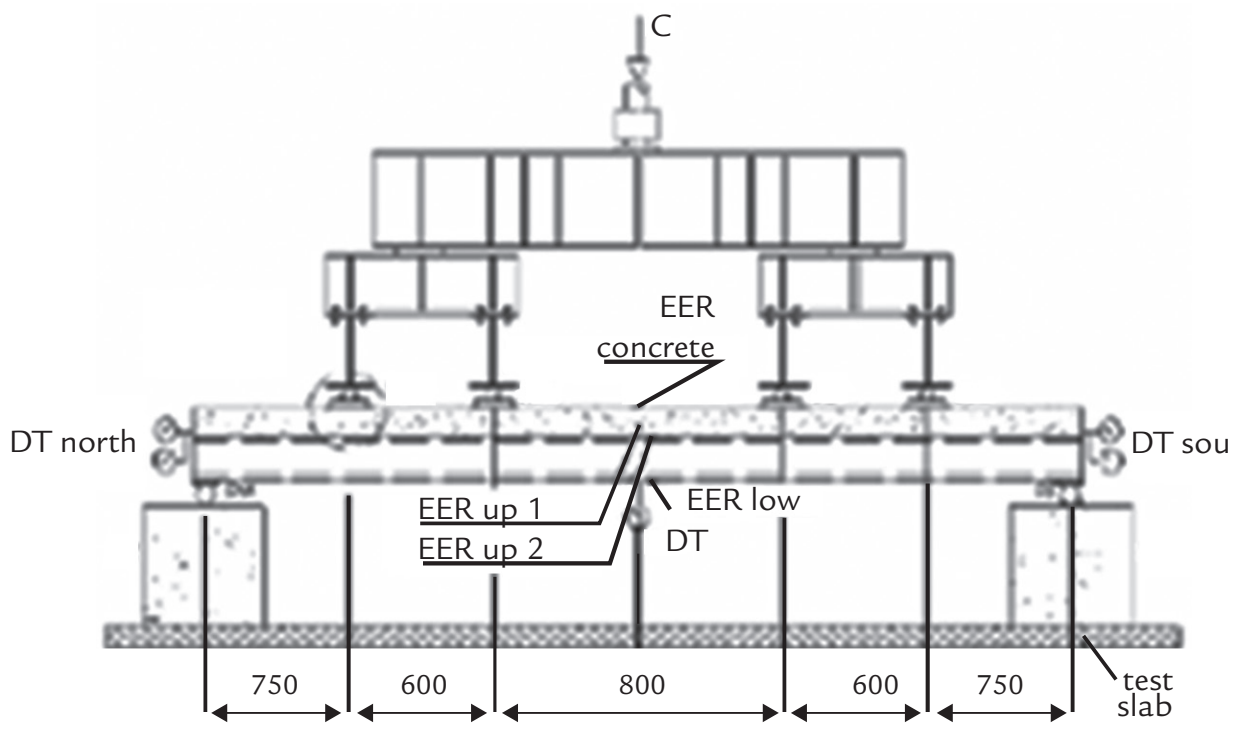

REM: R. Esc. Minas, Ouro Preto, 67(3), 253-258, jul. sep. | 2014255 


\subsection{Experimental results}

Figure 6 presents the beam responses in terms of bending moment $\mathrm{x}$ deflection at midspan section for all four tested models. It was possible to observe the favorable influence of friction to the beam stiffness and resistance. Collapse loads and bending moments can be found in Table 1, where

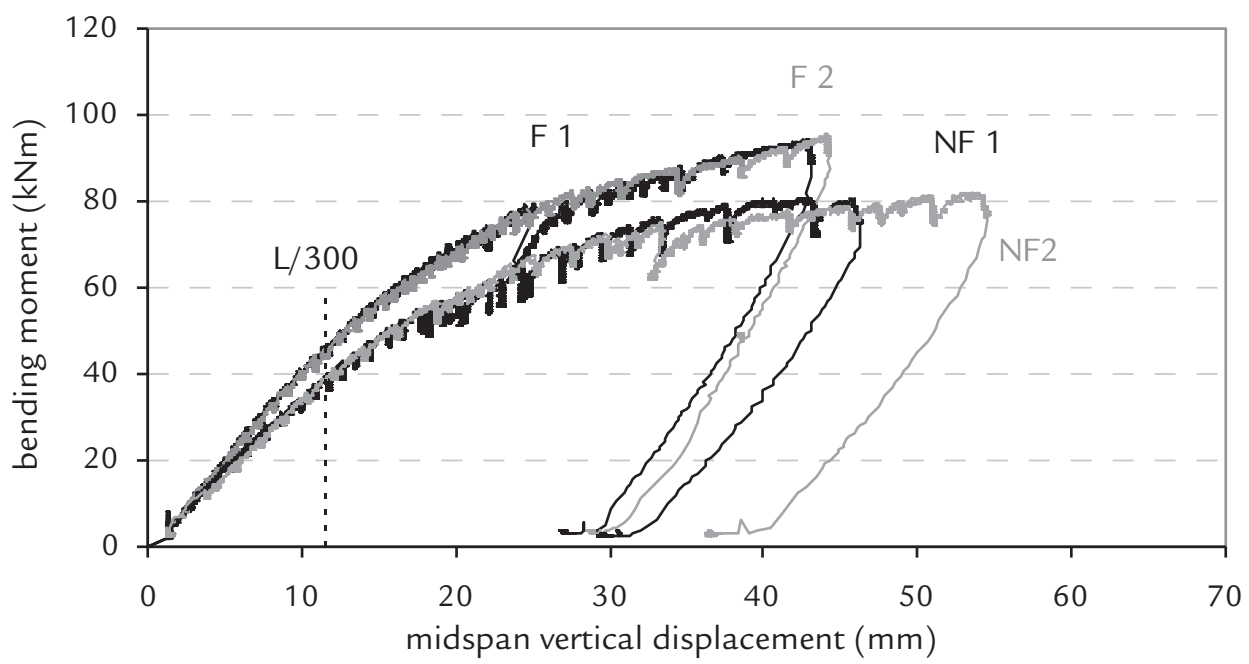

\begin{tabular}{c|c|c|c|c}
\hline Model & Collapse load $(\mathrm{kN})$ & $\begin{array}{c}\text { Collapse bending } \\
\text { moment } M_{c}(\mathrm{kNm})\end{array}$ & Average $M_{c}(\mathrm{kNm})$ & $\begin{array}{c}M_{c} \text { with friction } M_{c} \\
\text { without friction }\end{array}$ \\
\hline F1 & 174.2 & 94.3 & 94.8 & \\
\hline F2 & 176.2 & 95.4 & & \multirow{2}{*}{1.16} \\
\hline NF1 & 148.4 & 80.8 & & \\
\hline NF2 & 151.1 & 82.2 & & \\
\end{tabular}

\section{Numerical model}

A finite element model was developed allowing elastic and plastic analyses of simple or continuous composite beams, including friction at the interface, with any type of loading applied to the slab or to the I section profile. The software ANSYS version 11.0 and the following elements were used (see Figures 7):

1. Solid 65 - used to model the concrete slab; material modeling for compression consists of multilinear stress-strain curve and the Von Mises yield criterion (avoiding any stiffness degradation due to concrete crushing); William \& Warnke failure model allowing for cracking in the tension zone was adopted.

2. Shell 181 - used to model the it is shown that the ratio between the average collapse bending moments of the beams with friction and without friction achieved 1.16. This result was obtained for profiles with a painted surface, which means that higher values are expected for the untreated surface. Once the service steel profile, with Von Mises criteria, multilinear stress-strain relation and kinematic hardening;

3. Link 8-auxiliary elements used to model the shear connector spring at the slab center level ;

4. Link 10 - tension resistant only, used to avoid vertical separation between slab and steel profile;

5. Contac 12 - used to model the friction at the interface between slab and steel profile;

6. Combin 39 - nonlinear spring element used to model the load-slip curve of the shear connectors.

The $87.5 \mathrm{~cm}$ width concrete slab was modeled with 4 layers of solid elements across its $6.5 \mathrm{~cm}$ thickness. The transversal reinforcing bars were con- bending moment is defined as the one associated with the limit deflection equal to $\mathrm{L} / 300$, it can be noticed in Figure 6 that this moment corresponds to $46 \mathrm{kN}$.m for the beam with friction and to $40 \mathrm{kN}$.m to beam without friction, a difference of $11 \%$ assigned to the favorable effect of friction.

Figure 6

Bending moment deflection curves for the four models tested (Oliveira, 2009).

Table 1

Collapse load and bending moment $\mathrm{Mc}$ sidered as smeared throughout the solid finite elements of the two upper layers while the longitudinal ones were modeled within the elements in the region of their locations. Multilinear kinematic hardening model and Von Mises yield criterion are used for the rebars.

In the solution of the system of equations, incremental load steps varied in the range between 0.01 and $0.015 \%$ of the ultimate load.

In a previous study, a less refined numerical model was developed to simulate the experimental tests in which shell elements were used to discretize the slab (QUEIROZ et al., 2010). Concrete stiffness degradation after cracking in the tension zone was not considered in this model. 


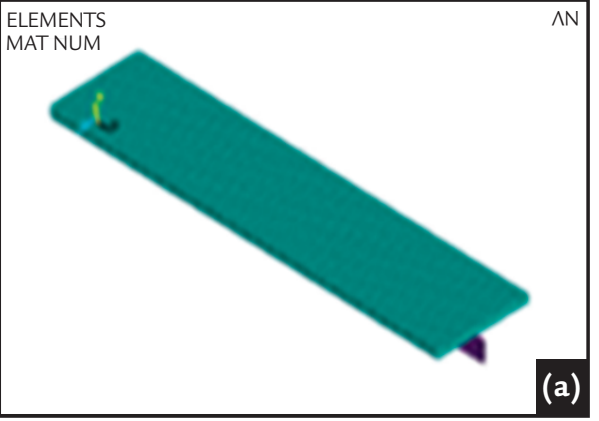

a)

Figure 7

Finite Element model using solid elements to simulate the slab.

(a) general view;

(b) detailed view;

(c) elements at the concrete-steel interface.

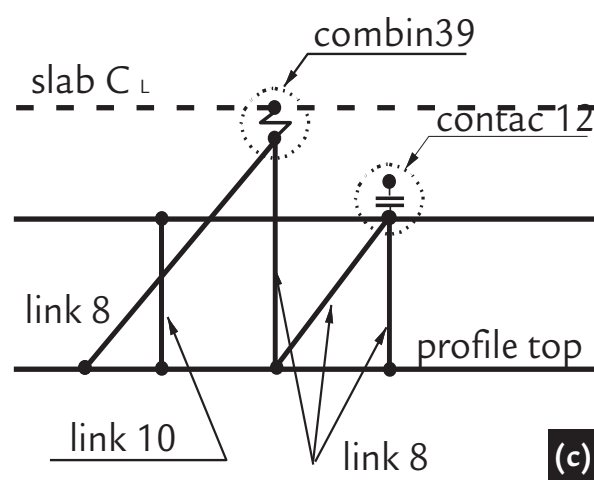

(c)

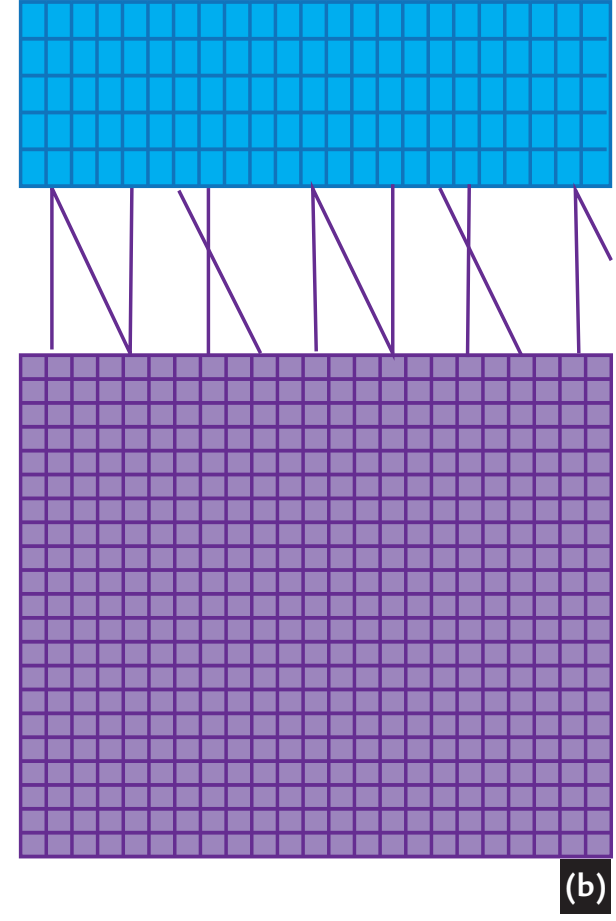

\section{Comparisons between numerical and experimental results}

The models of series $F$ and NF tested at the laboratory were simulated with the finite element models described in section 3. For that purpose the CFP box section was transformed to an equivalent I shape.

Figure 4 shows the connectors load slip curve (in dotted line) adopted in the numerical model.

Figure 8

Comparison between numerical and experimental results.

In both simulations, with and without friction, the "slab solid65" model displayed convergence problems and the analyses were precociously interrupted. Nevertheless, it can be noticed in Fig 8a that the result obtained with this model displayed a very good correlation with the NF1 test, without friction. For the case with friction (Fig. 8b), the behavior of the beam was well simulated by this model until half collapse load approximately; after

\section{Conclusions}

The results of experimental tests in simple composite beams showed that
The curve fitted to the experimental results was further adjusted to consider the lower number of shear connectors of the numerical model in each beam side (17 connectors) as compared to the physical model (22 connectors).

Figure 8 shows the comparison between the experimental results from the

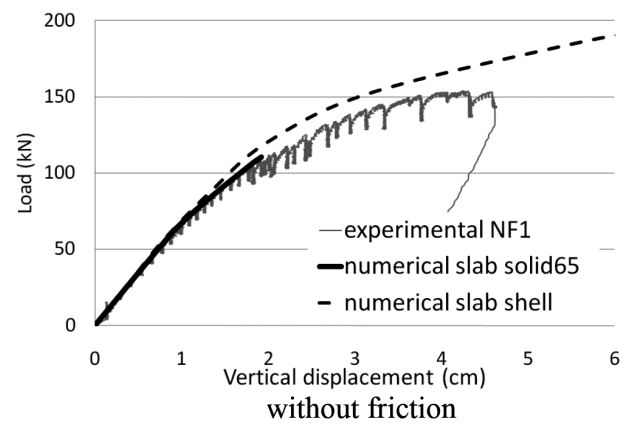

that load the numerical model presented greater flexibility than the experimental one. This can be explained by problems of friction simulation in the numerical model which, in this case, led to a significant difference in the results.

For the test without friction (Fig. 8a), the numerical model "slab shell" displayed a more rigid behavior than the model "slab solid65" and the physical model due to a poor simulation of the slab material, tests with and without friction and their numerical counterparts obtained with two models: the one described in section 3 in which solid elements were used to simulate the slab ("slab solid65) and the model presented in a previous study where shell elements represented the slab ("slab shell").

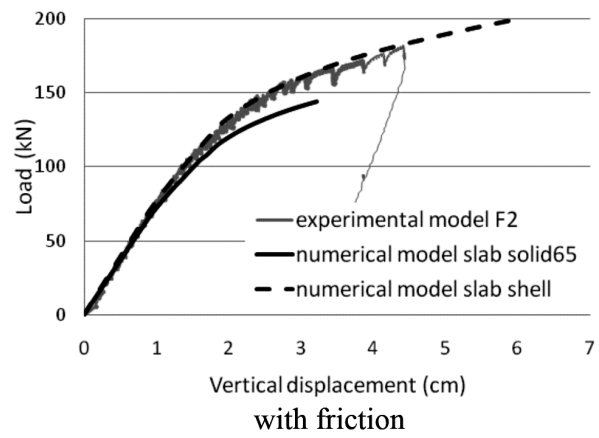

which does not take into account stiffness degradation after concrete cracking. On the other hand the simulation of the beam with friction (Fig.8b) seems to show a very good correlation with the experimental results but in this case two opposite effects contribute to this performance: the absence of the steel profile sheeting in the numerical model and the lack of appropriate modelling of the concrete in tension regions. friction at the interface between the slab and the steel profile plays an important role in the behaviour of short span beams with flexible connectors. For the 
$3.5 \mathrm{~m}$ span tested beams with connectors composed by bolts threaded to rivets, a $16 \%$ increase in collapse bending moment was assigned to the friction favorable effect. It became evident that not only the connector strength but also the connector stiffness should be considered in the design, specifically in deflection evaluation.

\section{Acknowledgments}

The authors gratefully acknowledge the financial support received from
The two numerical models developed to simulate the behavior of the tested beams exhibited very good correlations with the experimental results until approximately half collapse load. After that point, issues like concrete modelling in the tension zone and the absence of the profile sheeting in the numerical models contribute to a lower performance of their simulations. The more refined model using ANSYS element solid 65 displayed convergence problems which are currently being examined. Once validated, this numerical model may be used to simulate other practical situations for instance when part of the slab vertical reaction is supported by a transverse beam.

\section{References}

FAPEMIG (Fundação de Amparo à Pesquisa do Estado de Minas Gerais).

ABNT - Associação Brasileira de Normas Técnicas, Projeto e execução de estruturas de aço e de estruturas mistas aço e concreto de edifícios. NBR 8800, São Paulo, Brasil, 2008.

AISC - American Institute of Steel Construction, Load and Resistance Factor Design Specification for Structural Steel Buildings, Chicago, 2005.

ANSYS Version 11.0. Documentation. ANSYS, Inc.

BREMER C.F. Vigas mistas em perfis formados a frio com lajes mistas e lajes moldadas sobre painéis de concreto celular, Belo Horizonte: Universidade Federal de Ouro Preto, 2007. (D. Sc. Thesis).

OLIVEIRA, C.G.R. Análise teórico-experimental de vigas mistas com perfil formado a frio, flexibilidade dos conectores de cisalhamento e a influência do atrito entre o concreto e o aço do perfil, Belo Horizonte: Universidade Federal de Minas Gerais, 2009. (M.Sc Thesis)

QUEIROZ, G, RODRIGUES, F, PEREIRA, S; PFEIL; M; OLIVEIRA; C; MATA; L. Behavior of steel-concrete composite beams with flexible shear connectors, In: Proc. Stability and Ductility of Steel Structures (SSDS'Rio 2010), vol.1, p.863-870, Rio de Janeiro, 2010.

QUEIROZ, G., PEREIRA, S.S.R; MATA, L.A.C., SILVA, M., Influence of friction at the slab/steel profile interface and of the flexibility of shear connectors in steel - concrete composite beams, In: EUROMECH SOLID MECHANICS CONFERENCE, $7^{\text {th }}$.Lisbon, 2009.

SILVA M.C. Análise numérica de vigas mistas levando em conta a flexibilidade e a ductilidade dos conectores de cisalhamento bem com o atrito na interface entre o aço e o concreto, Belo Horizonte: Universidade Federal de Minas Gerais, 2009. (M.Sc. Thesis)

Received: 20 March 2013 - Accepted: 25 July 2014. 